\title{
町屋敷内部の構造と住民構成 (I)
}

\author{
一一江戸町人地の研究 (5) -
}

正会員王井哲 雄*

前章 ${ }^{1)}$ では，江戸日本橋町人地，及びその周辺に存在 した 29 ケ所の町屋敷をとりあげ，その内部の住居配置 の状態について, 享保期と文化期の比較, 分析を行っ た。その結果, 文化期においては, 日本橋町人地中心部 の主要街路に面した町屋敷の内部では, 地借町人の店舗 が大きな部分を占めるが，他の多くの裏通りの町屋敷で は，通りに面した表部分には地借町人の店舗が並ぶもの の, 裏部分には零細な店借の住居, つまりいわゆる裏長 屋が密集する内部状態が一般化することを示した。そし て，その上うな裏長屋の発生過程として，日本橋町人地 の外延部では, 既に, 享保期の時点で, ある程度の裏長 屋が都市下層民の住居として成立していたのに対して, 中心部分では, むしろ享保期以後の町人地階級内部の階 層分化の結果として, 裏長屋の住人たる下層町人が形成 されたのではないかとの推定を下した。この章では,こ のような構造をもつ江戸日本橋町人地の町屋敷が, 文化 期以後, 明治に至る幕末期に，どのような状態にあった かを，その住民構成の分析を主な手がかりとしてあきら かにしようとするものである。

$$
\text { 目次 }
$$

5-1 幕末期に打ける町屋敷類型

5-2 幕末期に扔ける町屋敷内住民構成（以上本号）

5-3 幕末期における町屋敷内住民の動向（以下次号）

5-4 町屋敷内住民の移動とその要因

\section{5一1 悬末期における町屋敷類型}

幕末期における町屋敷内部の状態を分析するために， ここでは主として, 明治初年の戸籍 ${ }^{2}$ 及び天保期の地代 店賃勘定目録 ${ }^{3)}$ を用いることにする。これは，前章で用 いたような町屋敷図が年代, 又は地域により，系統的に 残っているむのが少ないこと执よひ，この時期において 「人別改」などまとまった形で人口構成等の判明する史 料が，この日本橋町人地の場合，殆んど残っていない上 いうことによる。しかし，とくにこの明治初年の戸籍に よれば, 町屋敷内居住者全ての，名前（屋号），階層

(地主，借地，店借）の別，職種，住居坪数などが，明 治初年:の時点に限ってではあるが，日本橋本石町 2 丁目 及び日本橋町人地からややはずれてはいるが，かなりっ

\section{* 千䈎大学講師}

（昭和 52 年 6 月 30 日本稿受理・討論期限昭和 53 年 6 月术日）

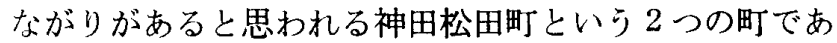
きらかにすることができる。一方，天保期の地代店賃勘 定目録の方からは，吉田市右衛門家が，日本橋町人地の 中に所有していた 7 ケ所の町屋敷について, 居住者の名 前 (屋号), 住居坪数, 更に地代, 店貣を 10 年以上にわ たってあきらかにすることができる。つをり，町屋敷内 部の住人の生活及びその社会的経済的背景や, 更にその 変化まで含めて検討しうるといら点でむしろ町屋敷図な どよりも有効な史料であるからである。ここで，一応， 問題之なるのは, 史料の時期, 及びその性格である。天 保期と明治初年との間は 30 年程度であるが，その間に 開国に始まり，明治維新に一応，帰結する政治的・経済 的変動の時期を含んでおり，江戸町人地にとっても幕末 期と一まとめできるほど平穏な時期ではなかったはずで ある。とくに明治初年の東京の史料がどの程度，江戸の

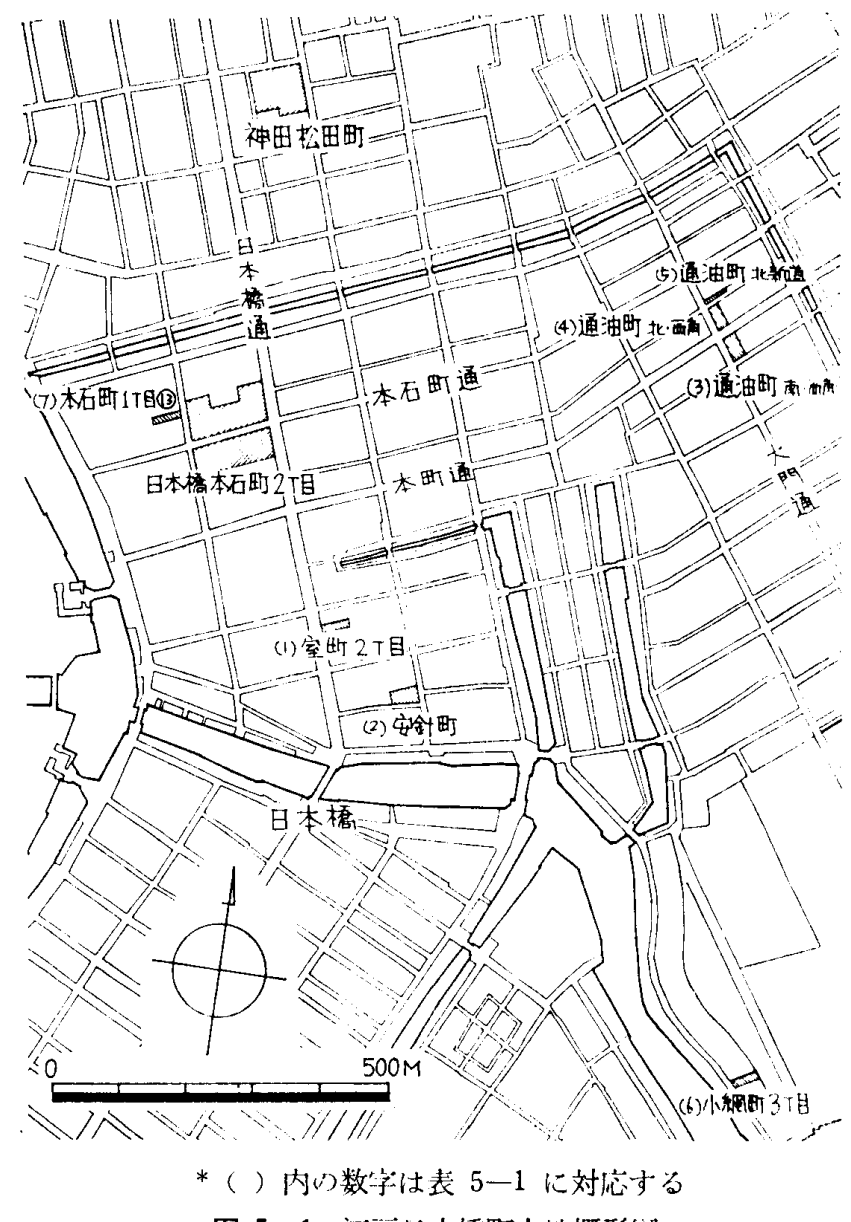

図 5-1 江户日本橋町人地概形図 


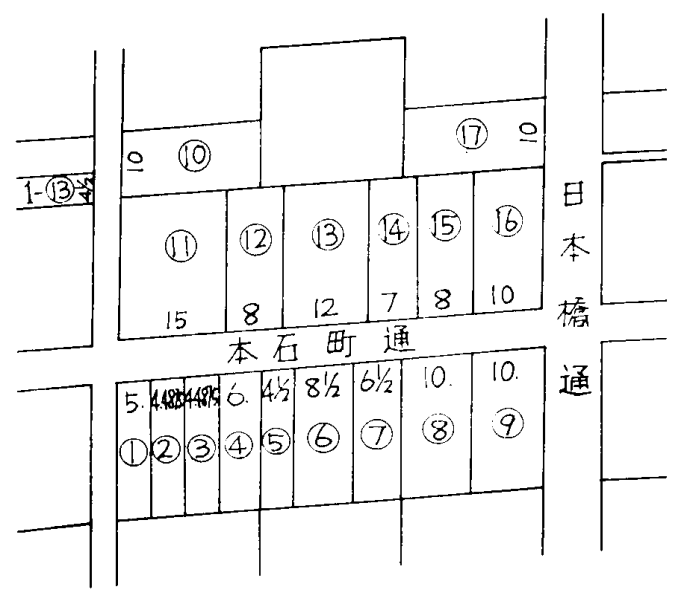

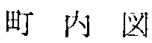

* O内の数当は地萑

** 閒口間数は宗間 $4^{1} / 2=4$ 閒半:

图 5-2(1) 日本橋本石町 2丁目

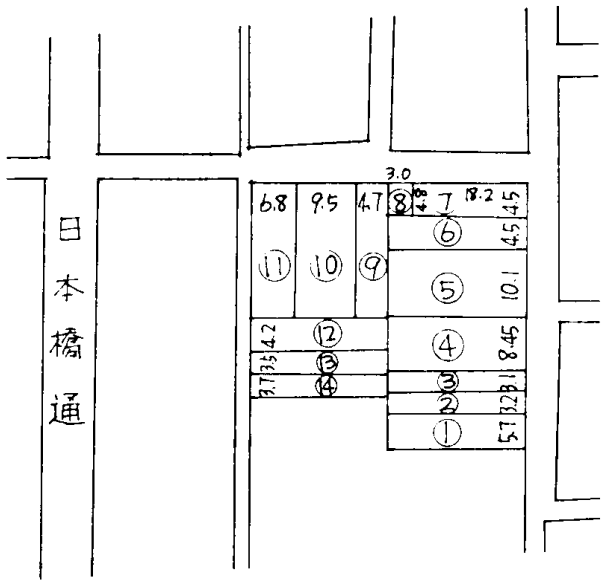

* ○内の数字は地番

** 䦎口間数は出舎間, 小数以卜は十進法に 換算した値

图 5-2（2）神田松田町町内図

表 5-1(1) 本石町 2丁目町屋教内部指標*

\begin{tabular}{|c|c|c|c|c|c|c|c|c|c|}
\hline 地 粹 & 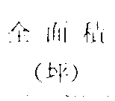 & 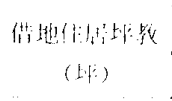 & 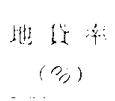 & 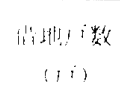 & 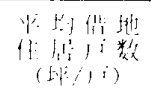 & 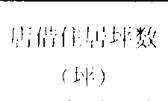 & 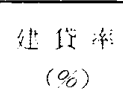 & $\begin{array}{c}M_{i} f_{f} f_{1} f=\text { 数 } \\
(1 i)\end{array}$ & 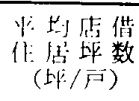 \\
\hline 1 & 117.36 & 51.85 & $(44.2)$ & 3 & 17.3 & 13.5 & $(11.5)$ & 2 & 6.8 \\
\hline (2) & 111.49 & $\ldots * *$ & - & & -- & & - & - & - \\
\hline 3 & 111.49 & $2(3.5)$ & $(23.8)$ & $?$ & 13.3 & 14.0 & $(12.6)$ & 3 & 4.7 \\
\hline (4) & 140.83 & 25.83 & $(18.3)$ & 2 & 12.9 & 44.0 & $(31.2)$ & 5 & 8.8 \\
\hline (5) & 105.62 & 96.0 & $(90.9)$ & 1 & 96.0 & & $-\cdots$ & - & - \\
\hline (6) & 199.51 & 45.5 & $(22.8)$ & 4 & 11.4 & 54.0 & $(27.1)$ & 8 & 6.8 \\
\hline (7) & 152.57 & 77.96 & $(\bar{i} \mid .1)$ & 6) & 13.0 & 39.0 & $(19.0)$ & 5 & 5.8 \\
\hline 8 & 23.72 & 130.0 & $(55.1)$ & $\therefore$ & 26.0 & 24.0 & $(10.2)$ & 3 & 8.0 \\
\hline 9 & 234.72 & 201.45 & $(85.9)$ & 8 & 25.2 & 5.25 & $(2.2)$ & 1 & 5.3 \\
\hline $10 \%$ & 231.72 & $108.5 * * *$ & $(16.2)$ & 4 & 27.1 & & & - & $\cdots$ \\
\hline an & $35 \% .08$ & $2+1.15$ & $(69.3)$ & 13 & 18.8 & 13.25 & $(3.8)$ & 3 & 4.4 \\
\hline 113 & $1 \times 7.7 i$ & 112.55 & $(50.9)$ & 6 & 18.8 & 25.25 & $(13.4)$ & 2 & 12.6 \\
\hline 13 & 281.66 & $5.6 * * *$ & $(1.8)$ & 1 & 5.0 & ..- & - & - & - \\
\hline (14) & 161.3 & $73.0 * * *$ & $(44.4)$ & 4 & 18.3 & - & -- & $\ldots$ & $\ldots$ \\
\hline (15) & 187.77 & 98.5 & $(52.5)$ & 2 & 49.3 & $\cdots$ & $\cdots$ & - & $\ldots$ \\
\hline 16: & 23.723 & 166.19 & $(70.8)$ & $\overline{5}$ & 33.2 & & - & $\cdots$ & $\cdots$ \\
\hline 17 & 234.7' & $37.5^{* * *}$ & $(16.0)$ & 1 & 37.5 & $\cdots$ & - & $\cdots$ & $\ldots$ \\
\hline$\hat{\imath} \|$ & 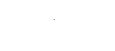 & . & & 66 & $\cdots$ & $\cdots$ & $\cdots$ & 32 & $-\cdots$ \\
\hline F. 1 & $\cdots$ & $\cdots$ & $-\cdots$ & - & 22.7 & - & -.. & - & 6.9 \\
\hline
\end{tabular}

*注（2）の更料（吅治 2 年 11 月）による。

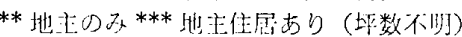

表 5-1(2) 神田松回町町屋敷队部指標*

\begin{tabular}{|c|c|c|c|c|c|c|c|c|c|}
\hline 地拈 & 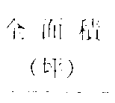 & 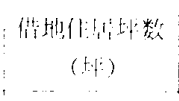 & 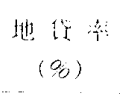 & $\begin{array}{c}\text { (1) itte i } x_{i x} \\
\text { (1) }\end{array}$ & 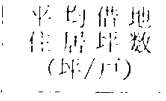 & 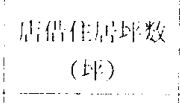 & 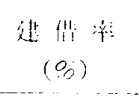 & $\begin{array}{c}J_{1} f_{1}\left(y_{1}\right) \text { i数 } \\
(1 i)\end{array}$ & 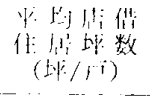 \\
\hline (1) & 126.85 & 17.5 & $(13.8)$ & 1 & 17.5 & 55.0 & $(43.4)$ & 13 & 4.2 \\
\hline (2) & 70.95 & .. & & $\cdots$ & -- & 22.5 & $(31.7)$ & 6 & 3.8 \\
\hline (3) & 69.88 & 43.75 & $(02.6)$ & 1 & 43.8 & 5.25 & $(7.5)$ & 1 & 5.3 \\
\hline (4) & 184.36 & 64.25 & $(34.9)$ & 3 & 21.4 & 39.0 & $(21.2)$ & 10 & 3.9 \\
\hline (5) & 223.0 & 35.0 & $(15.7)$ & 2 & 17.5 & 20.0 & $(9.0)$ & 5 & 4.0 \\
\hline (6) & 98.9 & 23.75 & $(24.0)$ & 2 & 11.9 & 48.0 & $(48.5)$ & 7 & 6.9 \\
\hline (7) & 93.98 & 20.0 & $(21.3)$ & 2 & 10.0 & 65.0 & $(69.2)$ & 8 & 8.1 \\
\hline (8) & 15.84 & $\cdots$ & - & $\cdots$ & - & 15.0 & $(94.7)$ & 2 & 7.5 \\
\hline (9) & 101.99 & 8.0 & $(7.8)$ & 1 & 8.0 & 46.33 & $(45.1)$ & 11 & 4.2 \\
\hline (10) & $200.6 !$ & 60.0 & $(39.9)$ & 2 & 30.0 & 88.5 & $(44.1)$ & 16 & 5.2 \\
\hline (11) & 147.0 & 69.73 & $(17.1)$ & 4 & 17.4 & 26.207 & $(17.9)$ & 4 & 6.6 \\
\hline (1) & 90.3 & 28.0 & $(31.0)$ & 3 & 9.3 & 36.75 & $(40.7)$ & 8 & 4.6 \\
\hline 13 & 73.5 & 36.75 & $(50.0)$ & .1 & 9.2 & 16.0 & $(21.8)$ & 2 & 8.0 \\
\hline 14) & 78.75 & 6.0 & $(7 . i j)$ & 1 & 6.0 & - & . & $\cdots .$. & $-\ldots$ \\
\hline 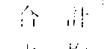 & $\cdots$ & $\ldots$ & $\cdots$ & 26 & 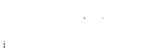 & $\cdots$ & - & 94 & - \\
\hline$t$ & & $\cdots$ & $\cdots$ & $\cdots$ & 15.9 & $\cdots$ & $\cdots$ & - & 5.1 \\
\hline
\end{tabular}

*注（2）の过料（明治 3 年4月）に上る 
表 5-1(3) 吉田家所有町屋敷内部指標*

\begin{tabular}{|c|c|c|c|c|c|c|c|c|c|c|}
\hline & 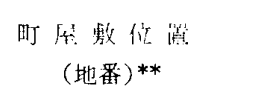 & $\begin{array}{l}\text { Ifi 䄳 } \\
\text { (块) }\end{array}$ & 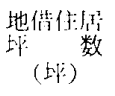 & $\begin{array}{l}\text { 地岱摔 } \\
(\%)\end{array}$ & $\begin{array}{c}\text { 地㑤户数 } \\
\text { (户) }\end{array}$ & $\begin{array}{c}\text { 将均地保 } \\
\text { 作居坪数 } \\
\text { (垟/月) }\end{array}$ & 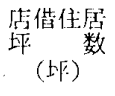 & $\begin{array}{l}\text { 貄仼㳯 } \\
(\%)\end{array}$ & $\begin{array}{c}\prod_{1}^{t} \text { 倛户数 } \\
(\vec{F})\end{array}$ & 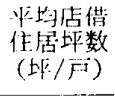 \\
\hline (1) & 穾剌 2 , 東，北卡り 2 & 140.83 & 114.45 & $(81.3)$ & 3 & 38.2 & - & $\ldots$ & - & - \\
\hline (2) & 㚣針町 & 283.9 & 197.6 & $(69.6)$ & 16 & 12.4 & - & - & - & -- \\
\hline (3) & 通椡町怙，西伯 & 260.0 & 259.45 & $(99.8)$ & 9 & 28.8 & - & - & $\cdots$ & - \\
\hline (4) & 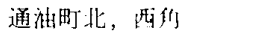 & 220.0 & 163.28 & $(74.2)$ & 11 & 14.8 & - & - & -- & - \\
\hline (5) & 通㳔町北新道 & 70.0 & 29.0 & $(41.4)$ & 1 & 29.0 & 39.0 & (55.7) & 6 & 6.5 \\
\hline (6) & 小網町 3 丁人1北上b 29 & 135.73 & 57.5 & $(42.4)$ & 3 & 19.2 & 45.0 & $(33.2)$ & 8 & 5.6 \\
\hline$(6)^{\prime}$ & [⿵冂⿱一口儿口 $f^{* * * *}$ & 135.73 & 55.42 & $(40.8)$ & 3 & 18.5 & 37.5 & $(27.6)$ & 8 & 4.7 \\
\hline (7) & A住明 1 - (13)*** & 105.62 & {$[35 * * * *$} & $(33.0)$ & 3 & $11.6]$ & 47.0 & $(44.5)$ & 11 & 4.3 \\
\hline
\end{tabular}

*注 (3) の东料比よる

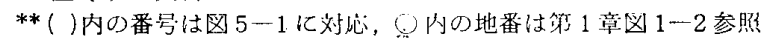

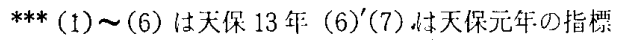

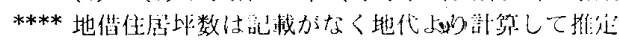

町屋敷史料として使えるかは不明な部分もある。しかし ながら，ここでは他优適当な史料もないので，まずこれ らの時期の史料から共通して検出できる特質をとらえ， 然る後にこの閒の町人地内部の変動，及びその意味を考 えていくことにしたい。

図 5-1 に江戸日本橋町人地, 及びその周辺の概形図 を示し, 本章で考察の対象とする町, 及び町屋敷の所在, 位置関係を示した。日本橋本石町 2 丁目（以下，本石町 とのみ略すことがある), 神田松田町 (以下, 松田町) については図 5-2 にそれぞれの町内図をあげ，町屋敷 の地番, 間口, を示した。更に表 5-1には, これら本 石町, 松田町の全ての町屋敷, そして, 吉田家が天保期 日本橋町人地において所有していた町屋敷（以下，吉田 町屋敷と略すことがある）７ケ所の町屋敷内部指標）を 計算して示し，表 5-2 には全ての町屋敷を示すことは できないので代表的と思われる町屋敷を選び町屋敷内の 具体的住民構成を, 町屋敷每に, 所帯主の名前, 職業, 住居坪数，家族数，召使数を階層別にして示した。

まず，表 5-1 にあげた個々の町屋敷内部指標から分 析できる町屋敷の特徽と外的条件との関係をとらえ，次 に町屋敷内部の具体的住民構成から, 町屋敷内部の住居 配置について考察することにする。

本石町の場合, 表 5-1 の内部指標からわかる町屋敷 内部の共通してみられる特徴は, 借地戸数が多く, 店借 戸数が少ないということである。(2)(5)(10(13)(14)(15)(16)(17)（地 番を示す，以下同様に略す）の町屋敷には店借が全くな い。残りの町屋敷も殆んどがせいぜい店借戸数 3 戸以内 である。店借戸数 5 戸以上で裹長屋らしいものが想定で きるのは(4)(6)(7) 3 例の町屋敷ぐらいである。したがっ て借地住居の占める比率, 即ち地貸率も高いものが多 い。地主住居を借地に含めることにすると殆んどが地 貸率が $60 \%$ をこえることになる。平均住居坪数は，借 地住居は 10 坪以上が大部分であり, 本石町全体の平均 をとると 20 坪をこえる。つまり，本石町は地貸率が高 く, 借地住居の場合でも比較的広いものが多く店借が少 ないということになる。
松田町の町屋敷内部指標をみると, 町全体として本石 町と朔逆に, 店借戸数が多く, 借地戸数が少ない町屋敷 が大部分であることに気つくく。図 5-2でわかるように 8)は小規模であり，とりあえず(7)8)を一つの町屋敷とみ なし，(14が借地 1 戸のみで大部分が明地と考えられるの

表 5-2(1) 本石町 2丁目, 松田町屋敷内住民構成例*

\begin{tabular}{|c|c|c|c|c|c|c|}
\hline $\begin{array}{l}\text { 朾名 } \\
\text { 地采 }\end{array}$ & 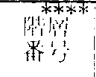 & 金 & 筬 丵 & 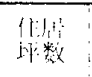 & 䅗族数 & 仔使数 \\
\hline $\begin{array}{c}\text { Aititio } \\
\text { (3) }\end{array}$ & $\begin{array}{l}\text { 地 } 1: 1 \\
\text { 借地 } 1\end{array}$ & 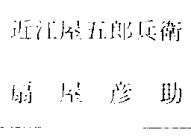 & 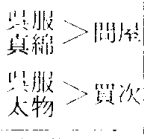 & $-0^{* * *}$ & $1^{* *}$ & $\begin{array}{l}31 \\
1)\end{array}$ \\
\hline 你们町 & $\begin{array}{r}\text { 借地 } 1 \\
2 \\
3 \\
4 \\
5\end{array}$ & 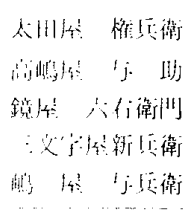 & 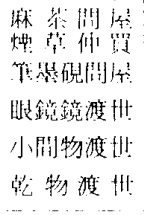 & $\begin{array}{l}95.23 \\
33.73 \\
14.99 \\
11.74 \\
10.5\end{array}$ & $\begin{array}{l}2 \\
5 \\
7 \\
3 \\
4\end{array}$ & $\begin{array}{r}12 \\
8 \\
2 \\
1 \\
-\end{array}$ \\
\hline 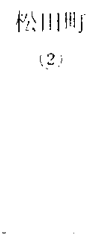 & 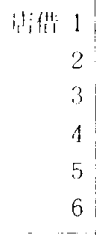 & 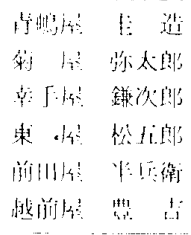 & 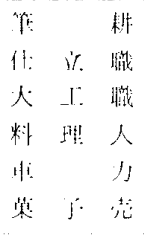 & $\begin{array}{l}3.75 \\
3.75 \\
3.75 \\
3.75 \\
3.75 \\
3.75\end{array}$ & $\begin{array}{l}4 \\
4 \\
4 \\
4 \\
6 \\
4\end{array}$ & $\begin{array}{l}- \\
- \\
\cdots- \\
\cdots \\
- \\
-\end{array}$ \\
\hline $\begin{array}{c}\text { Nittllij] } \\
3\end{array}$ & 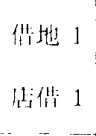 & 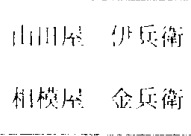 & 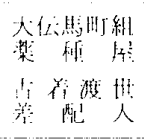 & 43.75 & 10 & -.- \\
\hline 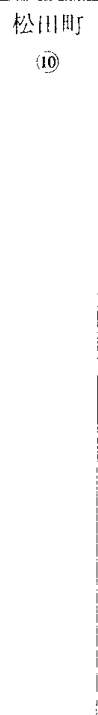 & 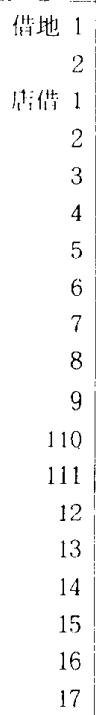 & 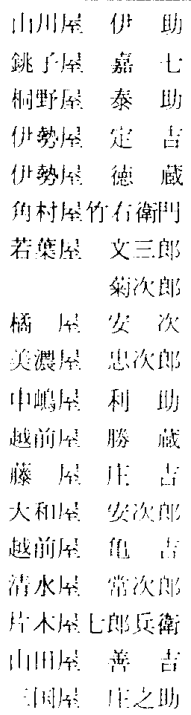 & 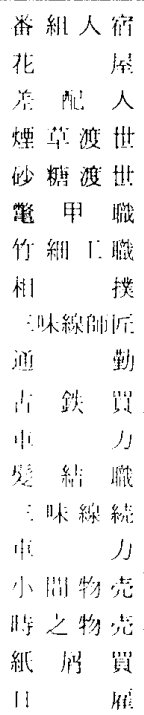 & $\begin{array}{r}40.0 \\
20.0 \\
10.0 \\
10.0 \\
8.0 \\
7.5 \\
5.0 \\
5.0 \\
5.0 \\
4.0 \\
4.0 \\
4.0 \\
4.0 \\
4.0 \\
4.0 \\
4.0 \\
4.0 \\
3.0 \\
3.0\end{array}$ & $\begin{array}{l}6 \\
4 \\
4 \\
3 \\
3 \\
4 \\
2 \\
4 \\
5 \\
8 \\
2 \\
5 \\
5 \\
4 \\
3 \\
5 \\
2 \\
5 \\
5\end{array}$ & $\begin{array}{c}\cdots \\
- \\
- \\
1 \\
- \\
3 \\
- \\
- \\
- \\
- \\
- \\
1 \\
- \\
\cdots \\
- \\
\cdots- \\
- \\
- \\
-\end{array}$ \\
\hline
\end{tabular}

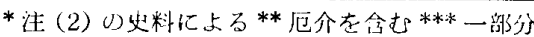
****階䚀内の順序は住居相模の順 
表 5-2(2) 吉田家所有町屋敷内住民構成例*

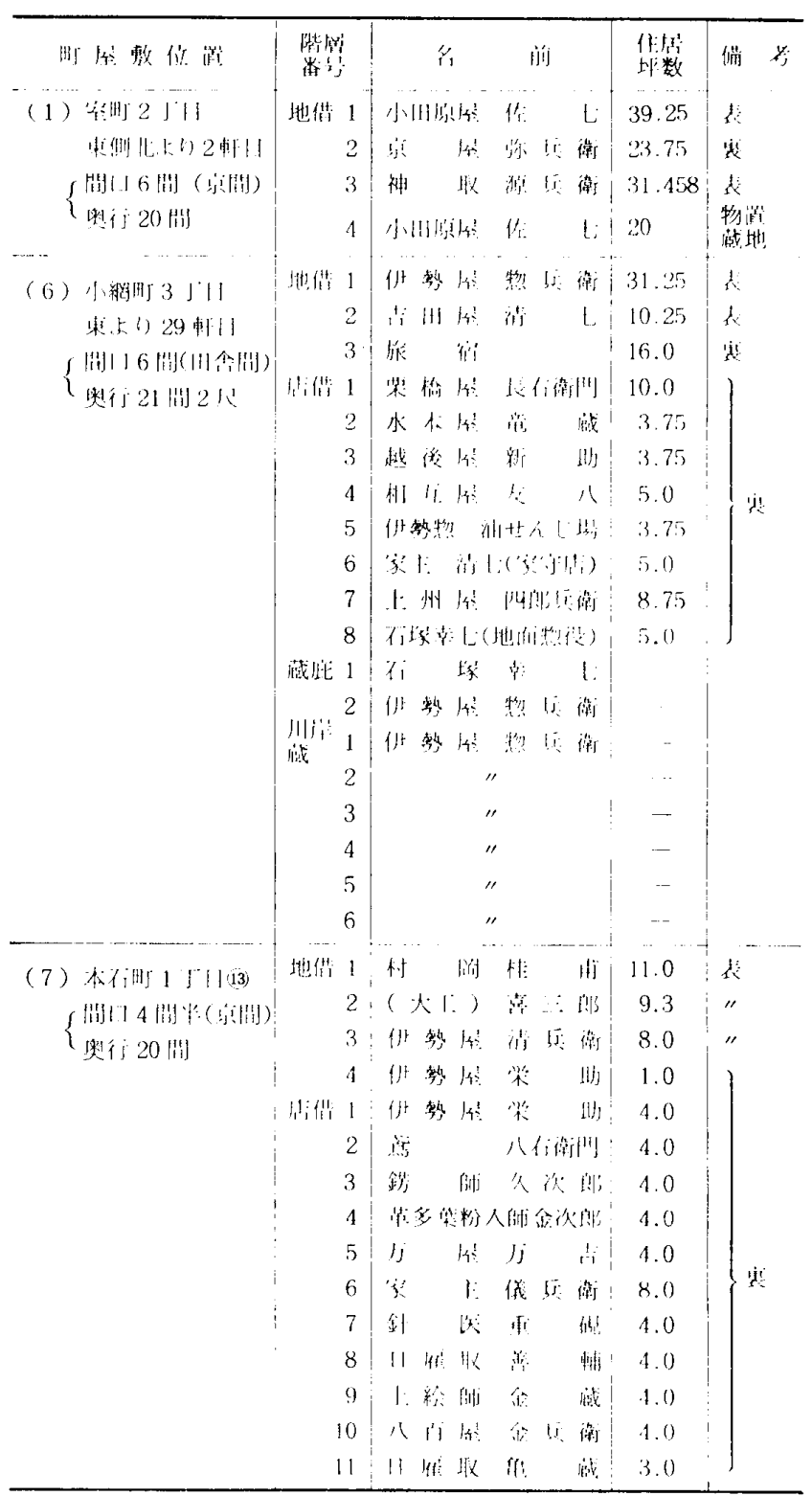

* $1:(3)+4+4+6 \leqslant$

でひとまず別にしておくと，(3)と(13)のが地貸率 50\% をこえ, 店借戸数が 1 2 戸と少ない例外的な町屋敷で あり，他の殆んどの町屋敷が，地貸率 30\% 程度以下と 低く, 店借戸数 5 戸以上の店借住居が密集するような特 徵を示していることがわかる。

次に吉田町屋敷の内部指標をみることにする。この吉 田町屋敷の場合, この 7 例の町屋敷は本石町, 松田町の ように地域的にまとまっている訳ではない。従って個々 の町屋敷の内部指標を別々に分析する必要があるが, こ

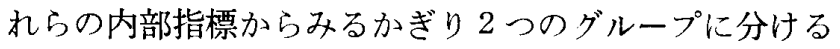
ことができょう。即ち，(1) の室町 2 丁目，(2) 安針 町, (3) 通油町南, 西角, (4) 通油町北, 西角の 4 例 と, (5) 通油町北新道, (6) 小網町 3 丁日, (7) 本石町 1 丁目の 3 例とではか次り町屋敷内部の様相が異なる。 访者（A グループとする）は店借戸数 0 であり地借戸数 が多く, 地貸率も全て $70 \%$ 程度以上と大きい。それに 対して後者（Bグループとする）は地借戸数は少なく,
せいぜい 3 戸であるのに，店借戸数が， 70 坪と小さい 町屋敷である通油町北新道でも 6 戸，他は 8 戸，11 戸 とかなり多いという共通の特徵をもっている。

つまり，この吉田町屋敷の両グループは町屋敷内部指 標でみる限り, 前者は本石町, 後者は松田町と, それぞ れ共通の特徴をもつといってよいであろう。となると， これら共通の特徴の成立する条件を考える必要がある。

そこで図 5-1により吉田町屋敷の町人地における位 置をみると，Aグループは，安針町が日本橋魚河岸の中 に含まれ，やや特殊な町屋敷であると思われるのでまず 除いて考えると，他の 3 例は，いずれも，主要街路に间 していることがわかる。即ち, 室町 2 丁目は日本橋通り に, 通油町の 2 例はいら゙れも本町通りと大門通りの交差 する角に，いゔれも面している。これは，本石町が，本 石町通りと日本橋通りとに面しており，その町屋敷も一 部を除いて本石町通りか，又は日本橋通りのいでれかに 面していることと同様である。つまり，地貸率が高く， 店借戸数が少ないといら町屋敷内部指標の特徵は, この 主要街路に面して間口をもつといら条件によると思われ る。

それに対して吉田町屋敷の中でBグループの町屋敷は いぶれも主要街路に面していない。通油町北新道は，大 阴通りに酉しているものの, 本町通りからははづれてい るし，小網町 $3 丁$ 目は日本橋川に面した河岸地にあるも のの，面している通りは裹通りである。本石町 1 丁目の 場合は，本石町通りから入った横町にのみ面した典型的 な裹通りの町屋敷である。そしてこのような条件は，松 田町が，日本橋通りとは一筋はづれた裏通りに面してい る位置にあることと同様である。つまり，地貸率が低 く, 店借戸数が多いという内部指標の特徴は, この上う な条件からくると考えてよい。

要するに，主要街路に面している町屋敷は地貸率が高 く, 裹通りの町屋敷の店借戸数が多いということで, こ れは, 前章で攻た文化期の町屋敷内部指標と街路との関 係と全く同様である。では次に，町屋敷内部の住居配 置, 街路との関倸についても同じことが云えるかどう か。この点をみるために, 表 5-2 に示した町屋敷内部 の住民構成によって住居配置を検討する。

まゔ，本石町では (13)をみることにする。この町屋敷 は，図 5-2 でわかるよ5に本石町通りに面した間口に 京間 12 間のかなり大きな町屋敷であるが，居住者は， 呉服・真綿問屋である近江屋五郎兵衛と，只服・太物買 次の扇屋彦助 2 戸しかいない。翮屋の方は, わうか 5 坪 であり，隣接した120中に 22.5 坪の借地をもっている ので，扔そらくこの 5 坪は (12)からはみ出した部分であ る。町屋敷全体にしてみればごく狭少である。つまりこ の町屋敷では近江屋五郎兵衛が, 地主でもあり, 住居坪 数は不明であるが，この町屋敷の大部分を占めていたと 
考えられる。しかも問屋といら業種, 及び 31 人という 召使数から考えて，かなりの大店舗を出していたことは 間違いない。本石町16は図 5-2 で示したように日本橋 通りと, 本石町通りの角地にあたり, 街路に面した表部 分が広い。住民構成は，麻苧問屋・煙草仲買の太田屋権 兵衛が 95.23 坪のかなり広い住居をもち，筆・墨・硯問 屋の高嶋屋与助も 33.73 坪の住居を持っている。この 2 戸は業種, 召使数からみて, 通りに面した店舗を出して いたとみられる。残りの 3 戸のうち，15 坪の眼鏡鏡渡 世である鏡屋六右衛門の場合も業種からみて店舗を出し ていた可能性が強い。つまり，この角屋敷内部では複数 の地借町人が通りに面した店舗を出していたとみられ る。

本石町と共通の特徵をもつ吉田町屋敷のAグループの 中で, 日本橋通りに面した室町 2 丁目は町屋敷内部が 4 つの部分に分れているが，居住戸数は実質的には 3 戸で ある。この町屋敷の場合, 地代から住居位置が推定でき るが ${ }^{6)}$ ，小田原屋佐七の 39.25 坪，神取源兵衛の 31.458 坪が通りに面した表にあり，京屋弥兵衛及び小田原屋佐 七の蔵地は裏部分にあたる。小田原屋佐七は本両替町組 両替屋でありフ，日本橋通りに面した店舗の意味は重要 であったと思われる。

以上ここでは 3 例しかあげられないが，本石町，及 び, 吉田町屋敷 A グループの町屋敷内部の住居配置の 特徴としては，主要街路に面して間口を持つ，1戸また は 2 3 戸のかなり大規模な店舗で町屋敷内部の大部分 が占められ，裏長屋などの店借住居の入り込む余地があ まりない。即ち前章で想定した町屋敷類型の「全戸地借 型」またはそれに近い型であるといえよう。

次に松田町, 及び, 吉田町屋敷 B グループの代表例を みることにする。まづ松田町 (10) をみると，この町屋敷 は図 5-2 でわかるように，日本橋通りに近い位置にあ り，間口も田舎間 9 間半とかなり大きく，松田町の中で は店舗を出すのに有利な場所である。住民構成は地借が 2 戸，そして店借がじっに 17 戸ある。しかも 3 坪，4 坪， 5 坪が 13 户もあり，これらは裹長屋とみてまちが いない。おそらく 3 棟以上の裹長屋が裹部分に建てられ ていたと思われる。地借の 2 戸は 40 坪と 20 坪であ り, 番組人宿, 花屋という職種からみて, 通りに店を出 していたのであろう。とすると，この町屋敷は「表地借 裹店借型」といらことになる。

吉田町屋敷中の本不町 1 丁目の場合もこの「表地借裹 店借型」である。この町屋敷はちょうど, 本石町 1 丁目 と 2 丁目の間の横町を北側に入ったところにあり，図 5 一2 の本石町10のちょうど向いにあたる位置であるが， 10 坪程度の地借が 3 戸，店借は 11 户で 8 坪上 3 坪が 1 戸ずつ，女上は全て 4 坪で， 2 棟の裏長屋が並んでいた とみられる。地借の 3 戸は, いら゙れも小規模であり, 店
舗を出していたかどうかは不明であるが，通りに面した 表に位置していたことは地代より確認できる。

松田町(2)は表 5-1 の内部指標では地借住居のない占 借のみの「表裹店借型」ということになるが, 表 5-2 に示したようにこの店借は全て， 3.75 坪で裹長屋とみ られ，また，建貸率 31.7\% と低いので明地があるとみ られる。おそらく，表地借部分が明地となっているので はないだろうか。

最後に, 吉田町屋敷（6）の小網町 3 丁目の町屋敷を とりあげたい。この町屋敷は本石町, 松田町, 吉田町屋 敷を含めて唯一の河岸地付である。河岸部分の河岸蔵は たまたま天保 13 年の時点では, 表部分に店舗を出して いると思われる，水油問屋である伊勢屋惣兵衛 ${ }^{\left({ }^{(B)}\right.}$ が借り 切っているが，他の時期は必ずしも一人が借り切ってお らず，頻繁に借り主が変っている場合も多い。したがっ てこの町屋敷にとってこの河岸蔵は重要な意味をもつと 思われるが，その問題は後節にゆう゚り，ここでは河岸地 を除いた部分で考えることにする。すると地借は 3 戸で あり，31.25 坪の伊勢屋惣兵衛は通りに面した表に店舗 を出していることは地代より確認できる。吉田屋清七の 10.25 坪も表であり，これも職種はあきらかではない が, 店舗を出していた可能性が強い。旅宿とは, 地主, 吉田市右衛門の江戸宿泊場らしいが，この 16 坪は表で はなく，裏である。裏には他に 2 棟 8 戸の長屋がある。 つまり,この日本橋川に面した河岸蔵のある町屋敷も, 河岸地を除いて考えれば，典型的な「表地借裹店借型」 と考えてよいことになる。

つまり, 以上の町屋敷内部指標及び住居構成からわか る町屋敷内部の住居配置と町人地における街路と堀との 関係加考えて幕末期に㧍ける江戸町屋敷の類型も，前 章8) でみたような文化期の町屋敷類型と基本的には変化 していないと考えられる。即ち, 文化期においては本町 通り日本橋通りなどの主要街路に面した町屋敷には地借 の商人が店舗を出しており，地貸率が高く「全戸地借型」 とでもいらべき, 町屋敷内に店借が全くいない町屋敷が 多かった。それに対して，主要街路からはづれた裏通り の町屋敷では, 通りに面した奥行 5 間程度の「表」部分 にのみ地借商人の店舗が並ぶものの, その奥の路次のみ に面した「裹」部分には裹店借の住居が密集する「表地 借裏店借型」が大部分であった。堀沿いの河岸地付町屋 敷の場合でも，河岸地を除いて考えればその殆んどが 「表地借裹店借型」であった。そして幕末期の町屋敷を

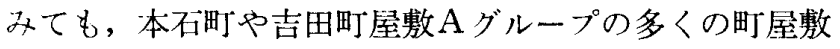
では，「全戸地借型」又はそれに近い型が多く, 松田町 や吉田町屋敷 B グループの多くの町屋敷では, 殆んど が「表地借裹店借型」といらことである。

つまり，文化期と幕末期の間では，町屋敷類型でみる かぎり, 決定的な変化は認められないといらことにな 
る。

\section{5一2 募末期における町屋敷内住民構成}

前節では, 本石町, 松田町, そして吉田町屋敷の町屋 敷類型を, 町人地における外的条件との関連から分析し た。この節では，町全体としての詳細な住居構成が判明 する本石町，松田町を例にとり，住民構成を分析し，江 戸町人地の住民構成について考察してみたい99。

表 5-3 は，前節で示した，全住民構成から本石町， 松由町，それぞれ職種と階層との関倸を集計して示した ものである。また表 5-4 は，階層別に，職種別に住居 坪数の分布を示したものである。表 5-5 と表 5-6 は， 各世帯構成員中の名使の数を示したもので, 表 5-5 は 職種，階層別に召使数分布を示したもの，表 5-6 は住 居坪数と召使数との相関関係を示したものである。

まず，全体の階層別内訳をみると，本石町は全103戸 中，地主が 5 戸，借地が 66 戸で，この雨方で $2 / 3$ 以上 を占め, 店借は 32 戸と少ない。これに対して, 松田町 では，120 戸中， 8 割近い 94 戸が店借で，借地は 26 戸，地主はいない。この点が本石町と松田町の大きな違 いである。これは前節でもみたように，本石町は，主要 街路に面して㧍り，松田町は裏通りにあるということか らくる上ころの, 個々の町屋敷内部の住民構成の集積と して一応説明できるが，町全体の住民構成としての性格 をあきらかにするためには，その階層内部の職種構成を 分析しておく必要がある。

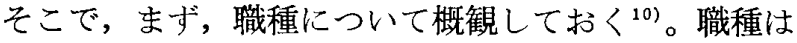
本石町が 68 種，松田町が 78 種を数えることができる。
表 5-3(1) 日本橋本石町 2 丁目階噘別職種構成*

\begin{tabular}{|c|c|c|c|c|c|c|c|c|c|}
\hline \multirow{3}{*}{ 職 } & \multirow{3}{*}{ 種! } & \multicolumn{5}{|c|}{ 陛 } & \multicolumn{3}{|l|}{ 別 } \\
\hline & & \multicolumn{2}{|c|}{ 地 } & \multicolumn{2}{|c|}{ 蔳地 } & \multicolumn{2}{|c|}{, } & \multicolumn{2}{|c|}{ 合 站 } \\
\hline & & F数 & $\begin{array}{c}\text { 構战 } \\
\text { 㱜 }\end{array}$ & Fi数 & $\begin{array}{c}\text { 笘成 } \\
1 t\end{array}$ & r数 & \begin{tabular}{|c} 
構战 \\
战
\end{tabular} & j) 数 & $\begin{array}{c}\text { 棉诚 } \\
\text { 比 }\end{array}$ \\
\hline \multirow{2}{*}{ 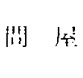 } & $y$ 数 & 4 & 80.0 & 5 & 7.6 & 0 & - & 9 & 8.7 \\
\hline & 满成生。 & 44.4 & - & 55.5 & - & -- & - & 100 & - \\
\hline \multirow{2}{*}{ 渡 世 } & r 数 & 1 & 20.0 & 46 & 69.7 & 15 & 46.9 & 62 & 60.2 \\
\hline & 静成比 & 1.6 & $\ldots$ & 74.2 & $\ldots$ & 24.2 & -- & 100 & -- \\
\hline \multirow{2}{*}{ 識 人 } & $r$ 数 & 0 & -- & 7 & 10.6 & 9 & 28.1 & 16 & 15.5 \\
\hline & 楛战此 & 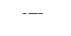 & - & 43.8 & . & 56.3 & & 100 & \\
\hline \multirow{2}{*}{ 雄 } & 户数数 & 0 & - & 8 & 12.1 & 8 & 25.0 & 16 & 15.5 \\
\hline & 構成此 & - & - & 50.0 & - & 50.0 & - & 100 & \\
\hline \multirow{2}{*}{ 合 } & $r$ 数 & 5 & 100 & 66 & 100 & 32 & 100 & 103 & 100 \\
\hline & 楞战比 & 4.9 & - & 64.1 & -. & 31.1 & - & 100 & - \\
\hline
\end{tabular}

表 5-3（2）神田松田町階層別職種满成*

\begin{tabular}{|c|c|c|c|c|c|c|c|c|c|}
\hline \multirow{3}{*}{ 㬝 } & \multirow{3}{*}{ 灀 } & \multicolumn{5}{|c|}{$P_{1}$} & \multicolumn{3}{|l|}{ 洌 } \\
\hline & & \multicolumn{2}{|c|}{ 地 1 : } & \multicolumn{2}{|c|}{ 借 地 } & \multicolumn{2}{|c|}{$\pi_{t} t_{i}$ 借 } & \multicolumn{2}{|c|}{ 会 豉 } \\
\hline & & ri数 & 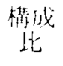 & 14数 & 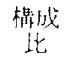 & fi数 & $\begin{array}{c}\text { 满线 } \\
\text { 化 }\end{array}$ & $j$ 'i数 & $\begin{array}{c}\text { 栗成 } \\
\text { 比 }\end{array}$ \\
\hline \multirow{2}{*}{$\operatorname{lin} 1 \%$} & $1 \mathrm{i}$ 数 & - & -- & 1 & 3.8 & $\cdots$ & $\cdots$ & 1 & 0.8 \\
\hline & 捗成比。 & - & - - & 100 & - & - & - & 100 & - \\
\hline \multirow{2}{*}{ 础 tit } & $F i$ 数 & - & - . & 11 & 43.3 & 32 & 34.0 & 43 & 35.8 \\
\hline & 㩐戊此 & - & $\cdots$ & 25.6 & - & 74.4 & $\cdots$ & 100 & - \\
\hline \multirow{2}{*}{ 樴 人 } & $j \quad$ 数 & - & - & 10 & 38.5 & 34 & 36.2 & 44 & 36.7 \\
\hline & 㭗战比 & - & $\cdots$ & 22.7 & - & 77.3 & - & 100 & - \\
\hline \multirow{2}{*}{ 架倠 } & $j i$ 数 & & & 4 & 15.4 & 28 & 29.8 & 32 & 26.7 \\
\hline & 栕戊计 & $\cdots$ & - & 12.5 & - & 87.5 & - & 100 & - \\
\hline \multirow{2}{*}{$\hat{A}$} & 今 数 & - & - & 26 & 100 & 94 & 100 & 120 & 100 \\
\hline & 情成比 & & - & 21.7 & - & 78.3 & & 100 & - \\
\hline
\end{tabular}

表 5-4(1) 日本橋本石时 2丁目住民住居坪数分布

\begin{tabular}{|c|c|c|c|c|c|c|c|c|c|c|c|c|c|c|}
\hline \multirow{3}{*}{ 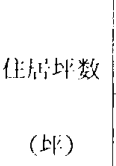 } & \multicolumn{4}{|c|}{ 肪 } & \multicolumn{5}{|c|}{ 醀 } & \multicolumn{3}{|l|}{ 纤 } & \multirow{2}{*}{$\widehat{\imath}$} & \multirow{2}{*}{ 部 } \\
\hline & 侣 & 地 & 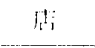 & 售 & 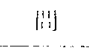 & 14: & 波 & tit & 職 & 人 & t & & & \\
\hline & $\begin{array}{l}f i \text { 数 } \\
(j i)^{2}\end{array}$ & $\begin{array}{c}\text { 㮐战比 } \\
(\%)\end{array}$ & $\begin{array}{c}17 \text { 数 } \\
\left(J^{i}\right)^{2}\end{array}$ & $\begin{array}{c}\text { 權伐计 } \\
\left(9_{0}\right)\end{array}$ & $\begin{array}{l}f^{i} \text { 数 } \\
(r i)\end{array}$ & $\begin{array}{c}\text { 㰌成比 } \\
\left(0_{0}\right)\end{array}$ & $\begin{array}{l}y^{i} \text { 数 } \\
\left(\gamma^{\prime}\right)^{2}\end{array}$ & $\begin{array}{c}\text { 楛誠此 } \\
(\%)\end{array}$ & $\begin{array}{l}j \text { 数 } \\
(j i)\end{array}$ & 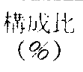 & $\begin{array}{l}y i \text { 数 } \\
(1,)^{2}\end{array}$ & $\begin{array}{c}\text { 满战比 } \\
(0.0)\end{array}$ & $\begin{array}{l}F \text { 数 } \\
\left(\mu^{-i}\right)\end{array}$ & $\begin{array}{c}\text { 棰成比 } \\
(96)\end{array}$ \\
\hline$\sim 5$ & 1 & 3.8 & 60 & 63.8 & - & -- & 17 & 39.5 & 26 & 59.1 & 18 & 56.3 & 61 & 50.8 \\
\hline$\sim 10$ & 11 & 42.3 & 34 & 36.2 & -- & - & 16 & 37.2 & 15 & 34.1 & 14 & 43.8 & 45 & 37.5 \\
\hline$\sim 15$ & 3 & 11.5 & $\cdots$ & & -- & -- & 2 & 4.7 & 1 & 2.3 & - & - & 3 & 2.5 \\
\hline$\sim 20$ & 5 & 19.2 & -- & - & $\cdots$ & -- & 4 & 9.3 & 1 & 2.3 & - & - & 5 & 4.2 \\
\hline$\sim 30$ & 3 & 11.5 & - & - & -- & - & 2 & 4.7 & 1 & 2.3 & - & - & 3 & 2.5 \\
\hline$\sim$ & 3 & 11.5 & - & - & 1 & 100 & 2 & 4.7 & - & - & - & - & 3 & 2.5 \\
\hline 合 湖 & 26 & 100.0 & 94 & 100.0 & 1 & 100 & 43 & 100.0 & 44 & 100.0 & 32 & 100.0 & 120 & 100.0 \\
\hline
\end{tabular}

表 5-4（2） 神田松田町住民住居坪数分布

\begin{tabular}{|c|c|c|c|c|c|c|c|c|c|c|c|c|c|c|}
\hline \multirow[b]{2}{*}{ 住作坪数 } & \multicolumn{2}{|r|}{ 隽 $\quad M$} & \multicolumn{2}{|l|}{ 别 } & \multicolumn{4}{|c|}{ 職 } & 重 & \multicolumn{3}{|l|}{ 別 } & \multirow{2}{*}{ 感 } & \multirow{2}{*}{ 計 } \\
\hline & 侎 & 地 & $\Gamma_{t}^{t_{1}}$ & 借 & [rin & 层 & 渡 & tit: & 满 & 人 & t & & & \\
\hline (坡) & $\begin{array}{l}f^{i} \text { 数 } \\
(1, i)\end{array}$ & $\begin{array}{c}\text { 㮐成此 } \\
(96)\end{array}$ & $\begin{array}{l}\prime i \text { 数 } \\
(1 i)^{\prime}\end{array}$ & $\begin{array}{c}\text { 檌成价 } \\
(\%)\end{array}$ & $r^{i}$ 数 & $\begin{array}{c}\text { 满戍此 } \\
(\%) \\
(\%)\end{array}$ & $\begin{array}{c}j \bar{y} \\
(j i)^{\text {数 }}\end{array}$ & $\begin{array}{c}\text { 楛成比 } \\
(\%)\end{array}$ & $\begin{array}{l}f^{i} \text { 数 } \\
(, i)\end{array}$ & $\begin{array}{c}\text { 權成比 } \\
(06)\end{array}$ & $\begin{array}{c}F^{3} \text { 数 } \\
\left(f^{i}\right)\end{array}$ & $\begin{array}{c}\text { 椑战比 } \\
(06)\end{array}$ & $\begin{array}{c}\mu^{j} \text { 数 } \\
(j-1)\end{array}$ & $\begin{array}{l}\text { 構成比 } \\
(\%) \text { ( }\end{array}$ \\
\hline$\sim 5$ & 1 & 1.5 & 10 & 31.3 & & - & 1 & 6.6 & 2 & 12.5 & 5 & 31.3 & 11 & 11.2 \\
\hline$\sim 10$ & 19 & 28.8 & 19 & 69.4 & & & 24 & 39.3 & 7 & 43.8 & 7 & 43.8 & 38 & 38.8 \\
\hline$\sim 15$ & 15 & 22.7 & 3 & 9.4 & & & 14 & 23.0 & 2 & 12.5 & 2 & 12.5 & 18 & 18.4 \\
\hline$\sim 20$ & 10) & 15.2 & & & & & 4 & 6.6 & 5 & 31.3 & 1 & 6.3 & 10 & 10.2 \\
\hline$\sim 30$ & 9 & 13.6 & & & 1 & 20.0 & 8 & 13.1 & $\cdots$ & -- & & $\cdots$ & 9 & 9.2 \\
\hline$\sim$ & 12 & 18.2 & $\cdots$ & $\therefore$ & 4 & 80.0 & 7 & 11.5 & $\cdots$ & -- & 1 & 6.3 & 12 & 12.2 \\
\hline 仓 it & 66 & 100.0 & 32 & 100.0 & 5 & 100.0 & 61 & 100.0 & 16 & 100.0 & 16 & 100.0 & 98 & 100.0 \\
\hline
\end{tabular}


表 5-5(1) 日本橋本石町 2 丁目職種階層別召使数分布

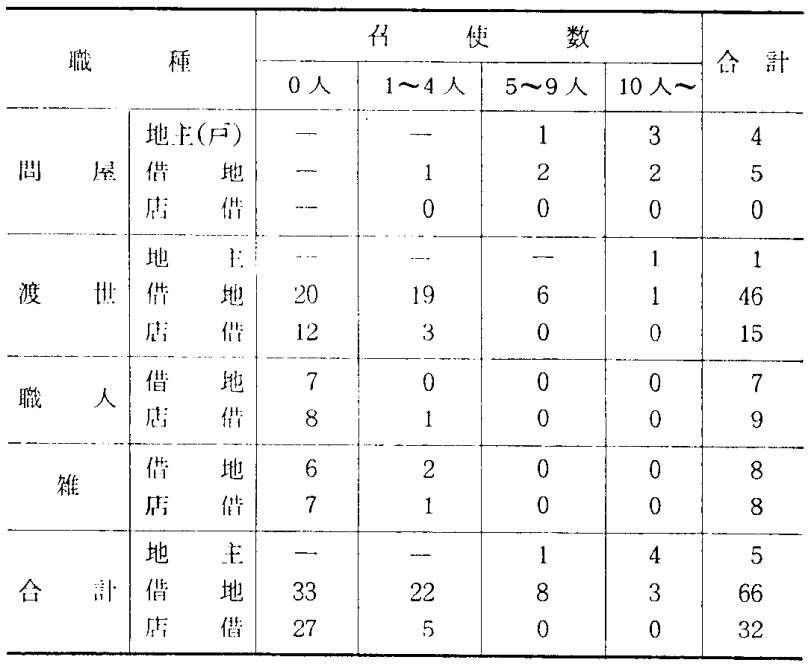

表 5-5(2) 神田松田町職種階層別召使数分布

\begin{tabular}{|c|c|c|c|c|c|c|c|}
\hline & $x$ & & & 8 & 数 & & \\
\hline माik & T". & & 0 人 & $1 \sim 4$ 人 & $5 \sim 9$ 人 & 10 人〜 & \\
\hline$[! ! 1]$ & 欍地(户 & & - & 1 & - & - & 1 \\
\hline [ii] & 店 & & - & 0 & - & - & 0 \\
\hline flt & 价 & & 9 & 2 & - & - & 11 \\
\hline w & 传i & 茎 & 31 & 1 & - & - & 32 \\
\hline 晴 & 借 & & 10 & 0 & - & - & 10 \\
\hline & $\Gamma_{t} l_{i}$ & 掉 & 31 & 3 & - & - & 34 \\
\hline 加 & 借 & 地 & 4 & 0 & - & - & 4 \\
\hline 稩: & & 集 & 27 & 1 & - & - & 28 \\
\hline$\hat{A}$ & 借 & 地 & 23 & 3 & - & - & 26 \\
\hline & re: & 借: & 89 & 5 & & - & 94 \\
\hline
\end{tabular}

その具体的内容については，必ずしも明きらかでないも のもあるが，一応 4 つのグループに分けることができ る。即ち, 第 1 は戸籍に問屋商人と明記してある「問屋 商人」のグループ。第 2 は, 〜買次, 〜仲買, 〜渡世, 〜 屋, 〜売と記してあるもの全てを含む「渡世グループ」 で,この問屋と渡世グループとが商人である。第 3 は, 職と記してあるものが大部分の「職人グループ」, そっ て最後は，これらのいずれにも分類しにくいものでこれ は「雑グループ」とした。この雑グループには, 職人な どよりも下層の都市雑業層と呼ばれるよらな町人が多く 含まれているものと思われる。

まず本石町の職種をみると，問屋が 9 戸ある。その種 類は呉服問屋が 3 戸あり，呉服問屋呉服渡世を兼ねる者 を含めると 6 户となる。これらはいずれも地主か，又は 借地でも住居規模の大きいものが多い。このことから問 屋グループというのは上層町人を構成していたとみるこ とが出来, この点は本石町の性格を考える場合かなり重 要なことだと思われる。

次に渡世グループである。これは 103 戸中，62 戸 (60.2\%) を占めている。即ち本石町の 住人の大半とい らことになる。内訳の職種は 40 種と多岐にわたってい るが，比較的多いのは魚渡世の 6 戸（魚屋も含めると 7
表 5-6(1) 日本橋本石町 2丁目住居規模召使数相関

\begin{tabular}{|c|c|c|c|c|c|c|}
\hline \multirow{2}{*}{\multicolumn{2}{|c|}{ 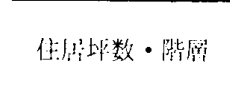 }} & \multicolumn{2}{|c|}{ 召 } & \multicolumn{2}{|c|}{ 数 } & \multirow{4}{*}{ 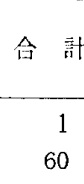 } \\
\hline & & \multirow{3}{*}{$\begin{array}{c}0 \text { 人 } \\
1 \\
58\end{array}$} & \multirow{3}{*}{$\begin{array}{c}1 \sim 4 \\
0 \\
2\end{array}$} & \multirow{3}{*}{$\begin{array}{c}5 \sim 9 \\
- \\
-\end{array}$} & \multirow{3}{*}{$\frac{10 \sim}{-}$} & \\
\hline $0 \sim 5$ & 借 地 & & & & & \\
\hline $0 \sim 5$ & 店 借 & & & & & \\
\hline \multirow{2}{*}{$\sim 10$} & 傅 地 & 11 & 0 & - & - & 11 \\
\hline & $\mathrm{r}_{\mathrm{i}} ; \quad$ 保 & 31 & 3 & -- & $-\infty$ & 34 \\
\hline \multirow{2}{*}{$\sim 15$} & 偡 地 & 3 & -.. & - & - & 3 \\
\hline & $\mathrm{I}_{1} \mathrm{t} ; \mathrm{fll}$ & 0 & ..- & $\cdots$ & - & 0 \\
\hline \multirow{2}{*}{$\sim 20$} & 傮 地 & 5 & $\cdots$ & $\ldots$ & - & 5 \\
\hline & It: & 0 & $\cdots$ & - & - & 0 \\
\hline \multirow{2}{*}{$\sim 30$} & 偕 地 & 2 & 1 & - & - & 3 \\
\hline & If & 0 & 0 & - & - & 0 \\
\hline \multirow{2}{*}{$\sim$} & 傅 地 & 1 & 2 & - & - & 3 \\
\hline & 店 倛 & 0 & 0 & - & - & 0 \\
\hline \multirow{2}{*}{ 合 計 } & 借 地 & 23 & 3 & - & - & 26 \\
\hline & 誌 & 89 & 5 & - & - & 94 \\
\hline \multicolumn{2}{|l|}{ 地 } & - & - & - & - & - \\
\hline \multicolumn{2}{|c|}{ 総 合 棓 $(\overline{F-1})$} & 112 & 8 & - & - & 120 \\
\hline
\end{tabular}

表 5一6（2） 神田松田町住居規模召使数相関

\begin{tabular}{|c|c|c|c|c|c|c|}
\hline \multirow{2}{*}{\multicolumn{2}{|c|}{ 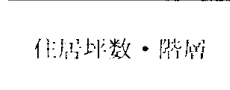 }} & \multicolumn{2}{|c|}{ 西 } & \multicolumn{2}{|c|}{ 数 } & \multirow{4}{*}{ 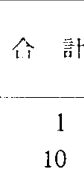 } \\
\hline & & \multirow{3}{*}{$\begin{array}{c}0 \text { 人 } \\
1 \\
10\end{array}$} & \multirow{3}{*}{$\frac{1 \sim 4}{-}$} & \multirow{3}{*}{$\begin{array}{c}5 \sim 9 \\
- \\
-\end{array}$} & \multirow{3}{*}{$\frac{10 \sim}{-}$} & \\
\hline $0 \sim 5$ & 借地 & & & & & \\
\hline $0 \sim 5$ & 供 & & & & & \\
\hline \multirow{2}{*}{$\sim 10$} & 偖 地 & 13 & 5 & 1 & - & 19 \\
\hline & 店 㑤 & 15 & 4 & 0 & - & 19 \\
\hline \multirow{2}{*}{$\sim 15$} & 啃 地 & 9 & 6 & -- & - & 15 \\
\hline & 基 借 & 2 & 1 & - & -- & 3 \\
\hline \multirow{2}{*}{$\sim 20$} & 供 此 & 9 & 1 & - & - & 10 \\
\hline & $n_{i} t_{i} \quad \mathbb{1}_{i}$ & 0 & 0 & - & $\cdots$ & 0 \\
\hline \multirow{2}{*}{$\sim 30$} & 借 地? & 1 & 5 & 3 & $\cdots$ & 9 \\
\hline & $\mathrm{n}_{\mathrm{i}}^{+}$偩 & 0 & 0 & 0 & - & 0 \\
\hline \multirow{2}{*}{$\sim$} & 借 地 & & 5 & 4 & 3 & 12 \\
\hline & $f_{1}^{\dagger} ; \quad$ 仵 & $\cdots$ & 0 & 0 & 0 & 0 \\
\hline \multirow{2}{*}{ 仓 int } & 借 地 & 3.3 & 22 & 8 & 3 & 66 \\
\hline & 䒚 & 27 & 5 & 0 & 0 & 32 \\
\hline \multicolumn{2}{|l|}{ 地 } & - & - & 1 & 1 & 5 \\
\hline 総 命 & 副 (F) & 60 & 27 & 9 & 7 & 103 \\
\hline
\end{tabular}

戸)，あとは吳服渡世の 4 戸，小間物渡世，菓子渡世， 乾物渡世の 3 戸である。呉服渡世が多いのは, 呉服問屋 が多いことと関係があるであろう。

次汇職人及び，雑グループであるが，これは，16 戸 づつで少ない。雑グループの中には通勤町人が 4 戸，こ れらはいずれも近くの商店に通勤しているらしい。ま た，雑グループに分類したはっきりとした職業をもたな い日雇稼，㦴日㕍，賃仕事などが合わせて7戸ある。

次に松田町の職種をみる。まず, 問屋は(3)の山田屋伊 兵衛の薬種問屋 1 戸のみで女る。渡世は 43 戸と全 120 戸中の $1 / 3$ 以上いるが，その内訳は 32 種の多岐にわた る。薬種屋, 薬種渡世と合わせて 4 戸あるのが数として は最も多い。これは松田町唯一の問屋商人である薬種問 屋との関係が想定できる。 
職人は 44 戸と最も多い。その内訳は 28 種にわたる が，大工職が 11 戸（宮大工を入れると 12 戸）いるの が注目される。大工職は職人の代表ともいえる存在であ り，神田が職人の町といわれることとも関連あると思わ れる。ついで雑グループも 32 戸と全戸数の $1 / 4$ 以上で 本石町に比べてかなり多い。その中では, 通勤町人が 4 戸あり，また，賃仕事 5 戸，日雇稼 3 戸，米春日雇 3 戸，日雇 2 戸と，いわゆる日雇取に含まれると思われる 者が 13 户とかなりの割合でいるのが目立つ。さらに， 雑グループの中で注目すべきことは, 本石町には全くみ られない車力が 5 户，東持が 2 戸あることである。これ らは，いずれも物資運搬に携わっている職種である。こ の背景としては, 松田町の位置が江戸町人地の中で, 中 仙道, 及びその延長としての日本橋通りからの江戸中心 部一の入口付近にあることが考えられる。しかも，その 日本橋通りの寸ぐ裹にあるたる物資運搬の荷役労働に関 係する仕事が，この周辺には多かったと考えてよいであ ろら。

以上によって階層，及び職種，それぞれの内訳があき

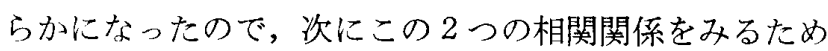
に, 階層別にその職種構成を, 住居坪数分布と関連させ て具体的にみていくことにする。

本石町の地主町人は 5 戸である。(10)の近江屋和助（只 服問屋, 召使 5 人) (13の近江屋五郎兵衛（呉服 - 真綿問 屋, 石使 31 人) (14)の槌屋藤右衛門（呉服問屋, 召使 21 人) (17)の唐木屋七兵衛 (小問物・呉服 -下り蛢燭問屋, 召使 17 人) が問屋商人であり, 召使数からみて, それ ぞれかなり大規模な店を出していることがわかる。(2)の 金沢屋三右衛門（菓子渡世，召使 12 人）も問屋商人で はないが町屋敷いっぱいに店を出していたと思われこ れら地主の店舗はすべて大店舗であったということにな る。しかも, これら地主:町人の場合, 他にも町屋敷を所 有している場合が多い11)。金沢屋三右衛門の場合，2 所, 近江屋和助が 4 ケ所, 槌屋藤左衛門が 3 ケ所, 唐木 屋七兵衛が 3 ケ所, そして近江屋五郎兵衛が本石町 $2 丁$ 目(4)(5)(6)含めてじつに 16 ケ所の町屋敷を所有してい る。つまり,これら地主町人達は商人としての営業規模 も大きく, 本石町の最上層を構成していたとみてよい。 また表 5-2 に示した(16)の太田屋権兵衛, 高嶋屋与助 も，ともに問屋商人であるが，この本石町 $2 丁$ 丁目に执い ては借地町人として店を出している。しかし，じつは他 の町に町屋敷を所有していたことがわかる。したがって 身分としては地主町人であり，住居規模から考えても上 層町人とみなせる。

次に本石町の借地町人の職種構成をみることにする。 まず，町屋敷を所有していない残りの問屋商人である が，表 5-4 の住居坪数分布をみてもわかるように，20 坪以上の店舗老出していることから上層町人と考えてよ
いであろら。渡世グループは借地 66 戸の 7 割近い 46 戸 (69.7\%) を占めるが，表 5-4 の住居坪数分布をみる と, 問屋商人が 20 坪以上だけであったのに 10 坪以下 から，30 坪以上まで広く分布していることがわかる。 これは，この借地であり渡世である町人 46 戸の中に上 層から下層まで多様な層が含まれていることを意味して いると思わ妃る借地の中でも職人, 雑グループは殆ん ど例外なく，住居坪数は 20 坪以下であり，20 坪をこえ るものはわずか 1 例にすぎず，この職人・雑の中に上層 町人は含まれているとは考えにくい。店借町人 32 戸の 場合は上りはっきりしていて，渡世 15 戸，職人 9 戸， その他 8 戸と分れているが, 全て住居坪数 15 坪以下で ある。つまり渡世であっても店借町人の中には上層町人 はいないとみてよい。

松田町の場合地主町人はいない。借地町人も 26 戸と 少ない。店借が 94 戸と最も多い。職種の内訳は問屋 1, 渡世 11 , 職人 10 , 雑 4 である。問屋商人は前にも述べ たが(3)の山田屋伊兵衛（大伝馬町組薬種問屋）であり， これは松田町における数少ない上層町人と考えられる。

一方, 借地中の職人・雑グループ合わせて 14 戸は殆 んどが 20 坪以下である。となると, 表 5-4(2) の借地 の住居坪数分布が 10 坪以下から 30 坪以上まで広く分 布しているのは, 本石町同様, 借地町人中の渡世グルー プに多様な層が含まれていることを示しているとみられ る。そして店借町人 94 户の内訳をみると, 渡世が 32 戸，職人が 34 戸，雑グループが 28 戸とほぼ同数とな る。この場合, 住居坪数分布をみると, 全てが 10 坪以 下ということがわかる。本石町同様, 店借町人に上層町 人はいないとみてよい。

このように住居坪数からみると, 本石町・松田町で, 一応, 問屋商人, 又は地主町人が上層町人を構成してい るとみられる。また,ここで一応, 住民坪数 20 坪程度 以上を上層である必要条件とみなすと, 店借町人には上 層町人はいないということになる。となると, 住居坪数 が広く分布していることから考えて, 問屋商人を除く借 地町人の性格に注目しなければならない。とくに借地町 人の中でも, 本石町では, 借地 66 戸中 7 割を占め, 松 田町でも最も数の多い渡世グループが江戸町人地の住民 構成を考える場合, 重要な意味をもつと思われる。とい 5のは, 本石町における呉服問屋, 松田町における車力 ・車持のように問屋商人・職人・雑グループの場合は, かなりはっきりと町の性格を決定ゔけているが，渡世グ ループの場合はこれほど明確ではない。このグループは 本石町にも松田町にも共通して存在している。これは渡 世グループが問屋や職人のように階層的に単一でなく, 存在基盤が様々である多様な層を含んでいるためであろ う。したがって江戸町人地の住民構成を分析しようとす ると, 階層的に特殊である問屋, 職人ではなく階層とし 
表 5-7 本石町, 松田町所带構成員比較

\begin{tabular}{|c|c|c|c|c|c|c|c|}
\hline i & & 标 & 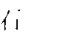 & inj & 松 & IHI & $|t| j \mid$ \\
\hline (1) & 地 1 : & 徏讪 & $l_{1} l_{i} l_{i t}$ & Â & 㖼撨 & $1,1:$ in & \\
\hline 安烧数（人） & 17 & 276 & 111 & 404 & 119 & $: 318$ & 467 \\
\hline 任 伎 数 & 85 & 127 & 8 & 220 & 7 & 7 & 14 \\
\hline$\hat{\imath}$ & 102 & $10: 3$ & 119 & $60^{2} 4$ & 1.6 & 357 & $48: 3$ \\
\hline
\end{tabular}

て相対的に一般的だと思われるこの渡世グループこそ考 察しておく必要があると思われるのである。

そこで, 渡世グループの商人としての営業規模といら 点に着目して表 5-5, 表 5一6により召使の有無, 及 びその数を考えることにしたい。召使の数は，表 5-7 に示したように総数は本石町 220 人, 松田町 14 人と本 石町が圧倒的に多い。その階層別内訳をみると, 店借町 人に雇われている召使は本石町 8 人, 松田町 7 人で, ほ ぼ同じで少ない。本石町の場合は, 上層町人である地主 5 戸にやはり 85 人が集中しているが，借地町人にも 127 人と多い。それに対して, 松田町の場合は借地町人 にわずか 7 人にすぎずかなりのちがいがある。そこで, 表 5一5(1) により数の多い本石町の借地の石使数分布 をみることにする。上層町人である問屋商人はやはり召 使のいない者はなく， 5 人以上が 4 戸，内 2 戸は 10 人 以上である。反対に職人には召使を置いている者はいな い。ところが, 渡世グループの場合, 召使無しが 20 戸，召使のいる者が 26 戸，内 5 人以上が 7 戸， 10 人以 上も 1 戸あり，やはり様々な層が含まれていることがわ 功。

そこでこの渡世を含めて営業規模としての住居坪数の 問題を考えるため住民坪数と召使数との相関関係を表 5 一6でみることにする。すると住居坪数 20 坪の上と下 とでかなり様相が異なっていることに気づく。といらの は, 召使数 0 の借地 33 戸中, 32 户までが 20 坪以下で あり，また 20 坪をこす 21 戸中，20 戸までが召使を置 いていて，しかも 5 人以上召使がいる 11 戸中，10 戸ま でが住居規模 20 坪をこえているこということである。

松田町の場合, 召使数が少なく, 本石町ほどはっきり しないが，召使のいない 23 戸中， 20 戸までは 20 坪以 下であり，召使がいる借地は 20 坪をこす場合に限られ ていることは，全く同様といえる。

以上のことから渡世グループを中心とする借地町人に とって, 住民規模 20 坪程度は一つの分れ目となってい るということである。20 坪以下では家内営業として石 使なしで営業できるのが，20 坪をこえると召使なしで は営業できにくい規模なのであろう。また，この 20 坪 は先に上層町人であるかどうかの目安として仮定した がここで一応の意味づけを与えることが可能となった と思われる。

つまり，あらためてまとめておくと，本石町，松田町
の戸籍の分析から想定できる江戸町人地の住民構成は, 地主町人, 又は借地であっても問屋商人などの大商人の グループが上層町人を構成する。一方, 職人, 及び商人 職人に分類しにくい䧱グルーブを中心とする店借町人が 下層を構成する。そして, 一部大商人を除く, 渡世と呼 ばれる商人を中心上する借地町人のグループは，上層か ら下層まで多様な層を含むが，住居規模でみると，だい たい20 坪程度が，上層下層の境目になる。即ち，20 坪 に達しない規模では, 召使など使用しない家族のみの営 業にとどまっているが，20 坪をこえると石使を置くよ らになり，営業規模としてもかなり大きくなるといらこ とである。

\section{[註]}

1) 拙稿「町屋敷内部の構造 と町人地の変質」一(論文報告集 255 号・ 1977)

2) 『日本橋本石町 2 丁目戸籍下書』(明治 2 年 (1869) ・東京 大学史料編纂所蔵)

『神田松田町戸籍』(明治 3 年（1870）・国立史料館蔵） これらの戸籍の成立過程及びその内容については, 本石 町については村田静子氏の紹介(「明治 2 年本石町 $2 丁$ 丁 局籍下書について」・日本歴史 218 号・1966) がある。松 田町の戸籍も時期がやや逯れるが, 形式, 内容からみて 全く同じ基準で作成された戸籍であると考えて上い。但 し下書ではないらしい。な抢，同様の户籍として「佃島」 のもの「下白金台町」のものが残っている。

3）『地代后貨勘定目録』類（国立史料館・吉田家文書） 武州幡羅郡下奈良村の吉田市右衛門が，宽政期以後，江戸 に执いて取得, 経営した町屋敷 11 ケ所の地代・店賃上り 高の記録である。装題は「勘定目録」の他に年により「勘 定目録帳」「勘定仕上帳」「勘定帳」などがあるが，内容 はほ济同椂であり，町屋敷每に，居住者名，地代，又心 店貨が記してあり，ての合計，及び町入用，普請修覆そ の他の町屋敷維持必要経費它差引いた純上り高の計算が ある。史料としてまとまっているのは文政 10 年から天保 13 年の 16 年間であるが, 全ての町屋敷につき, 全ての 分が揃っているわけではない。

4）ここで用いる町屋敷内部指慓は前章（註 1) で用いたも のと全く同様でるる(前竞 4-1 参照)。な抖不石町, 松 田町の戸籍で用いられている「借地」は内容から考えて, 地借と同じ意味と思われるが，一忘，戸籍に関しては借 地をそのまま用いておく。本稿では借地と地借は全く同 じ意味として使っている。

5）地主であっても，その町屋教内で営業している場合，何 らかの形で「地代」を哜上しており，経営体としてみる 場合には地借との区別法あまりないことが多い。

6）地代店貨勘定目録汇は「表坪」「裏坪」「角表坪」「新道表 坪」等の区別があり，坢当り単価も記してあるので，町 屋敷内部のどの位置に住居があるのか推定ができる。

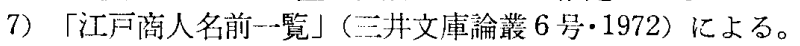

8) 前揭 (1)

9）本石町，松田町，ともに作成時期以後の書远み，及びは り紙による訂正により，所带，人員の移動が判明する。 しかしここでは, 便宜上, 本石町は明治 2 年 11 月, 松田 町法明治 3 年 4 月の戸籍作成時期の 住民構成に限定して 集計分析を行った。

な㧍, 本石町の関しては村田静子氏（註（2）前揭論文)， 松田町及び本石町に関しては松本四郎氏「幕末維新期に 扮许る都市支配の状況と打こわし」・村方騒動と世直し。 上」(1972 - 青木書店) 所収) に上る分析が行水れてい る。 
10）住民全体の職種の具体的名称については，村田静子，松 本四郎雨氏により既に紹介されており（注（2）(9）前揭 論文参照)，ここでは示していない。
11）これらの戸籍には所持地面の書込みがあり，町屋敷内の 住民が他に町屋敷を所有している場合, その場所, 坪数 が判明する。

\section{S Y N O P S I S}

U.D.C. $711.4 .03(521.27)$

\section{INHABITANTS IN MACHIYASHIKI \\ (RESIDENTIAL AREAS FOR TOWNSMEN) \\ by TETSUO TAMAI Lecturer of Chiba University, Member of A.I.J.}

Contents

5.1 Type of Machiyashiki in the Bakumatsu Era

5.2 Inhabitants in Machiyashiki in the Bakumatsu Era 